Original Article

Journal of National Institute of Neurosciences Bangladesh,

July 2019, Vol. 5, No. 2, pp. 156-160

ISSN (Online) 2518-6612

ISSN (Print) 2410-8030

\title{
Association of Haemoglobin and C-Reactive Protein level with Different Risk Factors among Acute Coronary Syndrome Patients
}

\author{
Md. Mahboob Morshed', Md. Joynul Islam², ATM Ashadullah³, Khondker Shaheed Hussain ${ }^{4}$, \\ Mohammad Ahtashamul Haque ${ }^{5}$ \\ ${ }^{1}$ Assistant Professor, Department of Cardiology, Shaheed Syed Nazrul Islam Medical College, Kishoregonj, \\ Bangladesh; ${ }^{2}$ Associate Professor, Department of Clinical Neurosurgery, National Institute of Neurosciences \& \\ Hospital, Dhaka, Bangladesh; ${ }^{3}$ Associate Professor, Department of Clinical Neurosurgery, National institute \\ of Neurosciences \& Hospital, Dhaka, Bangladesh; ${ }^{4}$ Associate Professor, Department of Cardiology, \\ National Institute of Cardiovascular Diseases, Dhaka, Bangladesh; ${ }^{5}$ Assistant Professor, Department \\ of Oral and Maxillofacial Surgery, Dhaka Medical College, Dhaka, Bangladesh
}

[Received: 10 April 2019 Accepted: 12 May 2019; Published: 1 July 2019]

\begin{abstract}
Background: Different risk factors may be related with the haemoglobin and CRP level among the acute coronary syndrome patients. Objective: The purpose of the present study was to see the association of haemoglobin and CRP level with different type of risk factors among the acute coronary syndrome patients. Methodology: This cross-sectional study was conducted in the Department of Cardiology at Mymensingh Medical College, Mymensingh, Bangladesh from December 2010 to November 2011 for a period of two (02) years. Patients of ACS who were presented within 12 hours of chest pain were included as study population. Study population were categorized in four groups according to the level of hemoglobin and C-reactive protein. Age, cardiovascular risks factor, history, family history of cardiovascular disease, treatment history and ECG were taken during admission. Blood sample was collected for baseline laboratory investigations like Troponin-I, Random Blood Sugar (RBS), Blood urea, Serum creatinine, lipid profile, Hemoglobin \& CRP level. Sample were then send to standard laboratory/Biochemistry department of MMCH. Result: The mean age of the population was $52.18 \pm 8.88$ years. Smoking was the highest percentage in Group 1 which was $54(50.0 \%)$ cases $(\mathrm{P}=0.001)$. Hypertension was found most common in group $1(47.6 \%)$, Group 2 (33.3\%), Group $3(10.7 \%)$ and Group $4(8.3 \%)$. Smoking $(\mathrm{p}=0.001)$ and hypertension $(\mathrm{p}=0.016)$ was found statistically significant. Diabetes was found in Group 1 (37.7\%), Group $2(43.5 \%)$, Group $3(11.6 \%)$ and Group $4(7.2 \%)$. Group $1(50 \%)$ and Group $2(50 \%)$ patients were dyslipidaemic. Family history of IHD was present group-1 (36.8\%), Group 2 (44.7\%), Group 3 (73.2\%) and Group 4 (53\%). Among the smoker patient $65.6 \%$ cases had CRP level $>12 \mathrm{mg} / 1 ; 39.8 \%$ cases had CRP level $<12 \mathrm{mg} / \mathrm{L}$. Among the nonsmoker $34.4 \%$ cases had CRP level $>12 \mathrm{mg} / 1$ and $60.2 \%$ cases had CRP level $<12 \mathrm{mg} / \mathrm{L}$. The finding was statistically significant. Conclusion: In conclusion haemoglobin and CRP level is associated with different type of risk factors among the acute coronary syndrome patients. [Journal of National Institute of Neurosciences Bangladesh, 2019;5(2): 156-160]
\end{abstract}

Keywords: Association; $\mathrm{Hb}$ and CRP level; different risk factors; acute coronary syndrome Patients

Correspondence: Dr. Md. Mahboob Morshed, Assistant Professor, Department of Cardiology, Shaheed Syed Nazrul Islam Medical College, Kishoregonj, Bangladesh; Email: mahboob3030@gmail.com; Cell no.: +8801819296183

Conflict of interest: There is no conflict of interest relevant to this paper to disclose.

Funding agency: This research project was not funded by any group or any institution.

Contribution to authors: Morshed MM, Islam MJ contributed from the protocol preparation, data collection up to report writing. Manuscript writing was performed by Ashadullah ATM, Hussain KS; Morshed MM performed the statistical model selection and analysis. Morshed MM has revised the manuscript. Haque MA was involved from the very beginning of this research work up to the revision of the manuscript as a supervisor, guide and director.

How to cite this article: Morshed MM, Islam MJ, Ashadullah ATM, Hussain KS, Haque MA. Association of Haemoglobin and C reactive protein level with Different Risk Factors among Acute Coronary Syndrome Patients. J Natl Inst Neurosci Bangladesh, 2019;5(2): 156-160

Copyright: (C2019. Morshed et al. Published by Journal of National Institute of Neurosciences Bangladesh. This article is published under the Creative Commons CC BY-NC License (https://creativecommons.org/licenses/by-nc/4.0/). This license permits use, distribution and reproduction in any medium, provided the original work is properly cited, and is not used for commercial purposes.

\section{Introduction}

Acute coronary syndrome (ACS) encompasses different clinical entities associated with acute myocardial ischemia including ST-segment elevation myocardial infarction (STEMI), non ST elevation myocardial infarction (N STEMI) and unstable angina ${ }^{1}$. Because of life threatening nature of an ACS, it is prudent to have a low threshold in suspecting a patient with acute chest 
pain as potentially having an ACS. Because the efficient diagnosis and optimal management of these chest pain are derived from information mostly only readily available from initial clinical presentation, there is overlap of those with true ACS and those that ultimately do not have CHD as a cause of their cardiac symptoms ${ }^{2}$. In addition, it may not be possible to differentiate patient with myocardial infarction from those with unstable angina in the initial hours as the biomarkers of myonecrosis can be normal initially ${ }^{3}$.

Incidence of ACS is increasing in developing countries including Bangladesh with socioeconomic improvement and change in the life style and dietary habit, smoking, decrease physical activity increasing body weight and consequently increasing rate of diabetes mellitus, hypertension and dyslipidemia which contribute to increase coronary heart disease $e^{4}$. Several factors are known to increase liability to coronary heart disease. The factors, which increases liability of CHD, some are modifiable, some are not. The factors which are established modifiable are smoking, hypertension, diabetes mellitus, dyslipidaemia, stress, obesity, sedentary work and so on ${ }^{5}$.

Low hemoglobin level has the potential to worsens the myocardial ischemic insult in acute MI and other acute coronary syndrome both by decreasing the oxygen content of the blood supplied to the jeopardized myocardium and by increasing myocardial oxygen demand though necessitating a higher cardiac output to maintain adequate systemic oxygen delivery ${ }^{6}$. Inflammation is a recognized key component of acute coronary syndrome, such pathogenic achievement has led to the use of inflammatory cells and protein as prognostic marker in these syndromes. Common markers of inflammation such as CRP, the prototypic acute phase protein and to lesser extent fibrinogen have been proven to be reliable and important markers of risk in ischemic heart disease ${ }^{7}$.

CRP in particular has been found be associated with short and long term prognosis in acute coronary syndrome including ST-elevation myocardial infarction and unstable angina and to predict the risk of re stenosis and major events including death after revascularization procedure $^{8}$. There are many studies on high $\mathrm{C}$ - reactive protein level correlated with coronary artery disease in the world. This present study was undertaken to see the association of haemoglobin and CRP level with different type of risk factors among the acute coronary syndrome patients.

\section{Methodology}

This comparative cross-sectional study was conducted in the Department of Cardiology at Mymensingh Medical College, Mymensingh, Bangladesh from December 2010 to November 2011 for a period of two (02) years. Patients of ACS who were presented within 12 hours of chest pain were included as study population. Patient who were admitted in CCU with clinical features of ischaemic type of chest pain of both sexes within 12 hours of onset of chest pain and diagnosed as ACS were included in this study. Patients with iron therapy before admission, blood transfusion before admission, History of previous or current haemostatic disorder, patient with recent bleeding, renal insufficiency, patient admitted with Chronic disease or inflammatory condition, Patient with malignancy, history of PCI or history of CABG were excluded from this study. All the data were recorded in a data collection sheet. Study population were categorized in four groups according to the level of hemoglobin and C-reactive protein. Patients who had less than $10 \mathrm{gm} / \mathrm{dl}$ haemoglobin level and more than or equal to $12 \mathrm{mg} / \mathrm{L}$ of CRP were designated as Group I. Patients who had more than $10 \mathrm{gm} / \mathrm{dl}$ haemoglobin level and less than 12 $\mathrm{mg} / \mathrm{L}$ of CRP were designated as Group II. Patients who had more than $10 \mathrm{gm} / \mathrm{dl}$ haemoglobin level and more than or equal to $12 \mathrm{mg} / \mathrm{L}$ of CRP were designated as Group III. Patients who had less than $10 \mathrm{gm} / \mathrm{dl}$ haemoglobin level and less than $12 \mathrm{mg} / \mathrm{L}$ of CRP were designated as Group IV. Age, sex, cardiovascular risks factor, history, family history of cardiovascular disease, treatment history and ECG were taken during admission. Blood sample was collected for baseline laboratory investigations like Troponin-I, Random Blood Sugar (RBS), Blood urea, Serum creatinine, lipid profile, Hemoglobin \& CRP level .Sample were then send to standard laboratory /Biochemistry department of $\mathrm{MMCH}$. The period of follow up was 5 days after admission. Permission from the ethical committee was taken. Continuous data were expressed as mean \pm SD. Categorical data were analyzed with test, Student's unpaired ' $t$ ' test was used for analysis of continuous variables. Comparison between groups was done by unpaired t-test. Avitex CRP (Omega Diagnostics Ltd. Scotland. UK) is a rapid latex agglutination test kit for detection of C-reactive protein in human serum. The detection limit is $6 \mathrm{mg} / \mathrm{L}$. Hemoglobin estimation was done by analyzer.

\section{Results}

Majority of the study population were in the age group 
Table 1: Age distribution of the study population

\begin{tabular}{lccccc}
\hline Age Group & \multicolumn{2}{c}{ Group Name } & \multicolumn{2}{c}{ Total } \\
\cline { 2 - 5 } & Group 1 & Group 2 & Group 3 & Group 4 & \\
\hline 30 to 40 Years & $11(14.7 \%)$ & $6(6.5 \%)$ & $5(22.7 \%)$ & $0(0.0 \%)$ & $22(10.9 \%)$ \\
41 to 50 Years & $23(30.7 \%)$ & $38(41.3 \%)$ & $7(31.8 \%)$ & $5(41.7 \%)$ & $73(36.3 \%)$ \\
51 to 60 Years & $28(37.3 \%)$ & $33(35.9 \%)$ & $8(36.4 \%)$ & $4(33.3 \%)$ & $73(36.3 \%)$ \\
61 to 70 Years & $13(17.3 \%)$ & $15(16.3 \%)$ & $2(9.1 \%)$ & $3(25.0 \%)$ & $33(16.4 \%)$ \\
Total & $\mathbf{7 5 ( 1 0 0 . 0 \% )}$ & $\mathbf{9 2 ( 1 0 0 . 0 \% )}$ & $\mathbf{2 2 ( 1 0 0 . 0 \% )}$ & $\mathbf{1 2 ( 1 0 0 . 0 \% )}$ & $\mathbf{2 0 1 ( 1 0 0 . 0 \% )}$ \\
\hline
\end{tabular}

Mean $\pm \mathrm{SD}=52.18 \pm 8.88 ; \chi 2=9.56, \mathrm{P}=0.39 \mathrm{NS} ;$ Group $1=\mathrm{Hb}<10$ gm/dl CRP $>12 \mathrm{mg} / \mathrm{L} ;$ Group 2=Hb $>10$ gm/dl CRP $<12 \mathrm{mg} / \mathrm{L} ; \mathrm{Group}$ $3=\mathrm{Hb}>10 \mathrm{gm} / \mathrm{dl} \quad \mathrm{CRP}>12 \mathrm{mg} / \mathrm{L} ;$ Group4 $=\mathrm{Hb}<10 \mathrm{gm} / \mathrm{dl} \quad \mathrm{CRP}<12 \mathrm{gm} / \mathrm{L}$

Table 2: Distribution of the study population by Risk factors

\begin{tabular}{|c|c|c|c|c|c|c|}
\hline \multirow{2}{*}{$\begin{array}{l}\text { Risk } \\
\text { Factor }\end{array}$} & \multicolumn{4}{|c|}{ Group Name } & \multirow[t]{2}{*}{ Total } & \multirow[t]{2}{*}{ P value } \\
\hline & Group 1 & Group 2 & Group 3 & Group 4 & & \\
\hline Smoking & $54(50.0 \%)$ & $39(36.1 \%)$ & $11(10.2 \%)$ & $4(3.7 \%)$ & $108(100.0 \%)$ & $0.001 \mathrm{~S}$ \\
\hline Hypertension & $40(47.6 \%)$ & $28(33.3 \%)$ & $9(10.7 \%)$ & $7(8.3 \%)$ & $84(100.0 \%)$ & $0.016 \mathrm{~S}$ \\
\hline Diabetes & $26(37.7 \%)$ & $30(43.5 \%)$ & $8(11.6 \%)$ & $5(7.2 \%)$ & $69(100.0 \%)$ & $0.93 \mathrm{NS}$ \\
\hline Dyslipidaemia & $4(50.0 \%)$ & $4(50.0 \%)$ & $0(0.0 \%)$ & $0(0.0 \%)$ & $8(100.0 \%)$ & $0.62 \mathrm{NS}$ \\
\hline IHD F/H & $14(36.8 \%)$ & $17(44.7 \%)$ & $5(13.2 \%)$ & $2(5.3 \%)$ & $38(100.0 \%)$ & $0.97 \mathrm{NS}$ \\
\hline
\end{tabular}

Group 1=Hb $<10 \mathrm{gm} / \mathrm{dl}$ CRP $>12 \mathrm{mg} / \mathrm{L}$; Group 2=Hb $>10 \mathrm{gm} / \mathrm{dl}$ CRP $<12 \mathrm{mg} / \mathrm{L}$; Group 3=Hb $>10$ gm/dl CRP $>12 \mathrm{mg} / \mathrm{L}$; Group4 $=\mathrm{Hb}<10$ gm/dl $\mathrm{CRP}<12$ gm/L; F/H=Family History; IHD=Ischaemic Heart Disease

of 41 to 50 Years and 51 to 60 Years of age group which were $73(36.3 \%)$ cases in each followed by 61 to 70 Years which was 33(16.4\%) cases. The mean age of the population was $52.18 \pm 8.88$ years. Statistically non-significant mean age difference among the groups (Table 1).

The common risk factors for acute coronary syndrome were compared at admission. Smoking was the highest percentage in Group 1 which was $54(50.0 \%)$ cases $(\mathrm{P}=0.001)$. Hypertension was found most common in group 1 (47.6\%), Group 2 (33.3\%), Group 3 (10.7\%) and Group $4(8.3 \%)$. Smoking $(\mathrm{p}=0.001)$ and hypertension $(\mathrm{p}=0.016)$ was found statistically significant. Diabetes was found in Group 1 (37.7\%), Group $2(43.5 \%)$, Group $3(11.6 \%)$ and Group 4 (7.2\%). Group $1(50 \%)$ and Group $2(50 \%)$ patients were dyslipidaemic. Family history of IHD was present group-1 (36.8\%), Group 2 (44.7\%), Group 3 (73.2\%) and Group 4 (53\%) (Table 2).

The mean CRP level of the study population was 10.63 $\pm 6.25 \mathrm{mg} / \mathrm{L}$, mean hemoglobin of the study population was $10.54 \pm 1.40 \mathrm{gm} / \mathrm{dL}$. The mean RBS of the study population was $10.55 \pm 6.40 \mathrm{mmol} / \mathrm{L}$. The mean Troponin I was $2.27 \pm 2.26 \mathrm{ng} / \mathrm{L}$ and the mean creatinine level was $1.56 \pm .44 \mathrm{mg} / \mathrm{dL}$ (Table 3).

Table 3: Biochemical parameters of the study population (Mean \& SD)

\begin{tabular}{lccccc}
\hline Biochemical & \multicolumn{2}{c}{ Group Name } & Total \\
\cline { 2 - 5 } parameters & Group 1 & Group 2 & Group 3 & Group 4 & $10.63 \pm 6.25$ \\
CRP & $15.20 \pm 4.56$ & $5.88 \pm 0.79$ & $17.45 \pm 7.84$ & $6.00 \pm 0.00$ & $10.54 \pm 1.40$ \\
$\mathrm{Hb}$ & $9.41 \pm 0.41$ & $11.51 \pm 1.33$ & $10.95 \pm 0.72$ & $9.42 \pm 0.79$ & $10.55 \pm 6.40$ \\
$\mathrm{RBS}$ & $10.05 \pm 4.48$ & $11.00 \pm 8.03$ & $9.84 \pm 4.82$ & $11.49 \pm 5.10$ & $2.27 \pm 2.26$ \\
Troponin-I & $2.64 \pm 2.59$ & $2.29 \pm 2.05$ & $1.21 \pm 1.28$ & $0.26 \pm 0.09$ & $1.56 \pm 0.44$ \\
S. Creatinine & $1.69 \pm 0.51$ & $1.51 \pm 0.41$ & $1.37 \pm 0.25$ & $1.42 \pm 0.22$ & \\
\hline
\end{tabular}

Group 1=Hb $<10$ gm/dl CRP $>12 \mathrm{mg} / \mathrm{L}$; Group 2=Hb $>10 \mathrm{gm} / \mathrm{dl} \mathrm{CRP}<12 \mathrm{mg} / \mathrm{L} ;$ Group 3=Hb $>10 \mathrm{gm} / \mathrm{dl} \quad \mathrm{CRP}>12 \mathrm{mg} / \mathrm{L}$; Group4 $=\mathrm{Hb}<10 \mathrm{gm} / \mathrm{dl} \quad \mathrm{CRP}<12 \mathrm{gm} / \mathrm{L} ; \mathrm{RBS}=$ Random blood sugar; $\mathrm{S}$. creatinine=serum creatinine; Hb=Haemoglobin; $\mathrm{CRP}=\mathrm{C}-$ reactive protein 
The association of CRP level with smoking was calculated. Among the smoker patient $65.6 \%$ cases had CRP level $>12 \mathrm{mg} / 1 ; 39.8 \%$ cases had CRP level $<12 \mathrm{mg} / \mathrm{L}$. Among the nonsmoker $34.4 \%$ cases had CRP level $>12 \mathrm{mg} / 1$ and $60.2 \%$ cases had CRP level $<12 \mathrm{mg} / \mathrm{L}$. The finding was statistically significant (Table 4).

Table 4: Correlation of CRP Level and Smoking Habit

\begin{tabular}{lcccc}
\hline Smoking & \multicolumn{3}{c}{ Total } & Significance \\
\cline { 2 - 3 } Habit & $<\mathbf{1 2} \mathbf{~ m g} / \mathbf{L}$ & $\mathbf{2 1 2} \mathbf{~ m g} / \mathbf{L}$ & & \\
\hline Smoker & $43(39.8 \%)$ & $61(65.6 \%)$ & $104(51.7 \%)$ & $\chi 2=13.297$, \\
Non smoker & $65(60.2 \%)$ & $32(34.4 \%)$ & $97(48.3 \%)$ & $\mathrm{P}=0.000$ \\
Total & $\mathbf{1 0 8 ( 1 0 0 . 0 \% )}$ & $\mathbf{9 3}(\mathbf{1 0 0 . 0} \%)$ & $\mathbf{2 0 1}(\mathbf{1 0 0 . 0} \%)$ & \\
\hline
\end{tabular}

Group $1=\mathrm{Hb}<10 \mathrm{gm} / \mathrm{dl} \mathrm{CRP}>12 \mathrm{mg} / \mathrm{L}$; Group 2=Hb $>10 \mathrm{gm} / \mathrm{dl}$ $\mathrm{CRP}<12 \mathrm{mg} / \mathrm{L}$; Group 3=Hb $>10 \mathrm{gm} / \mathrm{dl} \quad \mathrm{CRP}>12 \mathrm{mg} / \mathrm{L}$; Group4= $\mathrm{Hb}<10 \mathrm{gm} / \mathrm{dl} \quad \mathrm{CRP}<12 \mathrm{gm} / \mathrm{L}$

\section{Discussion}

This prospective observational study was carried out in the department of cardiology, Mymensingh Medical College Hospital, Mymensingh during the period of December 2010 to November 2011. This study was done to find out the correlation of hemoglobin and C-reactive protein with acute coronary syndrome and in hospital outcome.

Among the admitted patient in coronary care unit Mymensingh Medical College Hospital, a total of 201 patient diagnosed as acute coronary syndrome including unstable angina, non-ST elevation myocardial infarction \& ST elevation myocardial infraction were included in the study after considering the inclusion and exclusion criteria. The patients were divided in to 4 groups Group I, Group II, Group III and Group IV according to level of hemoglobin and C-reactive protein level. Among the 201 patient 75 patients were in Group I (Hemoglobin less than 10 $\mathrm{gm} / \mathrm{dl}, \mathrm{CRP}$ more than or equal to $12 \mathrm{mg} / \mathrm{L}), 92$ patients in Group II (Hemoglobin more than $10 \mathrm{gm} / \mathrm{dl}$, CRP less than $12 \mathrm{mg} / \mathrm{L}$,) 22 patients in Group III (Hemoglobin more than $10 \mathrm{gm} / \mathrm{dl}$, CRP more than 12 $\mathrm{mg} / \mathrm{L}$,) 12 patients included in Group IV (Hemoglobin less than $10 \mathrm{gm} / \mathrm{dl}$, CRP less than $12 \mathrm{mg} / \mathrm{L}$ ).

There were no significant difference of age distribution between these groups. The mean age of the patients were $52.18+8.88$ years. The highest percentage of group I were 51 to 60 years, and group II were 41 to 50 years, Islam et $\mathrm{al}^{9}$ found the mean age of the ACS patients were $53.60+8.5$ in Bangladeshi population. Enas and Senthilkumar ${ }^{10}$ found the mean age of ACS patients were $53.2+10.6$ years in Bangladeshi population which supported the finding of present study.

The common risk factors for acute coronary syndrome were compared at admission. Smoking was the highest percentage in Group 1 which was 54(50.0\%) cases $(\mathrm{P}=0.001)$. Hypertension was found most common in group 1 (47.6\%), Group 2 (33.3\%), Group 3 (10.7\%) and Group $4(8.3 \%)$. Smoking $(\mathrm{p}=0.001)$ and hypertension $(p=0.016)$ was found statistically significant. Diabetes was found in Group 1 (37.7\%), Group $2(43.5 \%)$, Group $3(11.6 \%)$ and Group 4 (7.2\%). Group $1(50 \%)$ and Group $2(50 \%)$ patients were dyslipidemia. Family history of IHD was present group-1 (36.8\%), Group 2 (44.7\%), Group 3 (73.2\%) and Group 4 (53\%). At baseline, group I and group II has significant difference regarding the presence of smoking, hypertension, diabetes and has no significant difference regarding dyslipidemia and family history of IHD. Group III and Group IV were not considered as there were small number of cases. Among the risk factor smoking and hypertension were most prevalent in group-I than group-II and they were $(50 \%$, vs $36.1 \%)$ and $(47.6 \%$,vs $33.3 \%)$, diabetes was more prevalent in group II than Group-I $(43.5 \%$, vs $37.7 \%)$. Smoking and hypertension were statistically significant. The mean C-reactive protein level was in Group- $\mathrm{I}=15.20+4.56 \mathrm{mg} / \mathrm{L}$, Group-II $=5.88+0.79$ $\mathrm{mg} / \mathrm{L}$, Group-III $=17.45 \mathrm{mg} / \mathrm{L}$ and Group IV $=6.00$ $\mathrm{gm} / \mathrm{L}$. The mean C-reactive protein level in Group-I was consistent with Majumder et $\mathrm{al}^{11}$ where the finding was $15.57+12.85 \mathrm{mg} / \mathrm{L}$ in a group.

The mean hemoglobin concentration was $9.41 \pm 0.041$ in group I, $11.51 \pm 1.33$ in group II, $10.95 \pm 0.72$ in Group-III and Group-IV= 9.42+.79 gm/dl. The mean hemoglobin concentration was $10.54+1.40 \mathrm{gm} / \mathrm{dl}$, which was discordant with the finding of Lipsic et $\mathrm{al}^{12}$ where the mean hemoglobin concentration was $12.9 \pm 0.04 \mathrm{gm} / \mathrm{dl}$. Anker et $\mathrm{al}^{2}$ where base line mean hemoglobin was $12.6 \pm 1.3 \mathrm{gm} / \mathrm{dl}$ in women and $13.7 \pm 1.4 \mathrm{gm} / \mathrm{dl}$ in men in ACS patients.

There was no significant mean difference among group 1 , group 2, group 3 and group 4 considering random blood sugar level $(10.05 \pm 4.48 \mathrm{mmol} / \mathrm{L}, 11.00 \pm 8.03$ $\mathrm{mmol} / \mathrm{L}, 9.84 \pm 4.82 \mathrm{mmol} / \mathrm{L} 11.49 \pm 5.10 \mathrm{mmol} / \mathrm{L})$, serum creatinine $(1.69 \pm 0.51,1.51 \pm 0.41,1.37 \pm 0.41$, $1.42 \pm 0.22)$ and Troponin I $(2.64 \pm 2.59$, $2.29 \pm 2.05,1.21 \pm 2.05,0.26 \pm 0.09$ ).

Smoker have high C-reactive protein level than nonsmoker $65.6 \%$ have CRP level more than $12 \mathrm{mg} / \mathrm{L}$ and $39.8 \%$ have CRP level less than $12 \mathrm{mg} / \mathrm{L}$. Nonsmokers $34.4 \%$ have CRP level $>12 \mathrm{mg} / \mathrm{L}$ and 
$60.2 \%$ have CRP level less than $12 \mathrm{mg} / \mathrm{L}$. There was a significant relationship between CRP and smoking. This data is consistent with Moghbeli et $\mathrm{al}^{13}$. Where they found despite fewer traditional risk factor, smokers who had ACS had higher CRP level than nonsmoker.

\section{Conclusion}

In conclusion haemoglobin and CRP level is associated with different type of risk factors among the acute coronary syndrome patients. So categorizations of patient with ACS on basis of hemoglobin and CRP level may help for risk stratification and management. Hemoglobin and CRP count is a simple, affordable and widely available test which is easily done for each and every patient admitted in the hospital. Establishment of hemoglobin and CRP level as a risk factor for ACS needs further large scale study.

\section{References}

1. Kim MC, Kini AS, Fuster B. Definition of acutecoronary syndromes. In: Fuster V, Alexander RW, O'Rourke RA, Wilson PP. (eds). Hurst's the heart 12th ed. New York: McGraw-Hill, 2009;1311-20

2. Anker SD, Voors A, Okonko D, Clark AL, James MK, Von Haehling S, Kjekshus J, Ponikowski P, Dickstein K. Prevalence, incidence, and prognostic value of anaemia in patients after an acute myocardial infarction: data from the OPTIMAAL trial. European heart journal. 2009;30(11):1331-9.

3. Antman EM, Braunwald E. ST-elevation Myocardial infarction, pathology, pathophysiology and clinical features. In: Zipes D P, Livvy P, Bomow R 0, Braunwald E (eds). Braunwald's heart disease a test book of cardiovascular medicine. 7 th ed. Philadelphia: W B Saunders; 2005;1141-65
4. Malik A, Islam MN, Jafar A, Ramizuddin M, Kadir AK. Clinical pattern of ischaemic heart disease and its association with some known risk factors. Bangladesh Heart Journal 1987;2:1-9

5. Bloomifield P, Bradbury A, Grubb N. R., Diseases of cardiovascular system. In: Boon AN, Colledge RCN, Walker RB, Hunter AA. 2006. Davidson's principles and practice of medicine cardiovascular disease 20th ed. Edinburgh London New York oxford Philadelphia: Churchill Livingstone. 2006;579-81

6. Levy PS, Kim SJ, Eckel PK, Chavez RO, Ismail EF, Gould SA, Ramez Salem M, Crystal GJ. Limit to cardiac compensation during acute isovolemic hemodilution: influence of coronary stenosis. American Journal of Physiology-Heart and Circulatory Physiology. 1993;265(1):H340-9.

7. Sarnak MJ, Tighiouart H, Manjunath G, MacLeod B, Griffith J, Salem D, Levey AS. Anemia as a risk factor for cardiovascular disease in The Atherosclerosis Risk in Communities (ARIC) study. Journal of the American College of Cardiology. 2002;40(1):27-33. 8. Al-Ahmad A, Rand WM, Manjunath G, Konstam MA, Salem DN, Levey AS, Sarnak MJ. Reduced kidney function and anemia as risk factors for mortality in patients with left ventricular dysfunction. Journal of the American College of Cardiology. 2001;38(4):955-62.

9. Islam AM, Majumder AA. Coronary artery disease in Bangladesh: A review. Indian heart journal. 2013;65(4):424-35

10. Enas EA, Senthilkumar A. Coronary artery disease in Asian Indians: an update and review [online] Internet J Cardiol. 2001: 1. 11. Majumder AA, Karim MF, Rahman MA, Uddin MA. Study of association of C-reactive protein with coronary collateral development. Cardiovascular Journal. 2010;3(1):26-32.

12. Lipšic E, van der Horst IC, Voors AA, van der Meer P, Nijsten MW, van Gilst WH, van Veldhuisen DJ, Zijlstra F. Hemoglobin levels and 30-day mortality in patients after myocardial infarction. International journal of cardiology. 2005;100(2):289-92.

13. Moghbeli N, Kirtane AJ, Ray KK, Murphy SA, Gibson CM, Braunwald E, Cannon CP, TIMI Study Group. C-Reactive Protein and Cardiovascular Outcomes in Smokers Versus Nonsmokers in Non-ST-Elevation Acute Coronary Syndrome (from the TACTICS-TIMI 18 Trial). The American journal of cardiology. 2005;96(5):635-8. 